\title{
Post Windstorm Evaluation of Critical Aspects Causing Damage to Rural Houses in the Northern Region of Peninsular Malaysia
}

\author{
Shaharudin Shah Zaini ${ }^{1,}$, Taksiah A. Majid ${ }^{1}$, Siti Noratikah Che Deraman ${ }^{1}$, Farah \\ Alwani Wan Chik ${ }^{1}$, and Mohd Khairul Azuan Muhammad ${ }^{1}$ \\ ${ }^{1}$ Disaster Research Nexus, School of Civil Engineering, Universiti Sains Malaysia, Engineering \\ Campus, Penang, Malaysia
}

\begin{abstract}
Rural houses are susceptible to roof blown off and severe damage during a windstorm event due to the lack of engineering considerations. The aim of this paper is to conduct a post windstorm evaluation on the damaged rural houses located in the northern region of Peninsula Malaysia. Several activities were involved during the post windstorm survey including site visualization, site measurement and interview. Critical aspects including types of damages, types of houses, gap height, overhang length, roof geometry, roof pitch, roof cladding and terrain category were analysed using a simple bar chart. It is anticipated that the presence of kitchen house influences the overall stability of the rural houses due to the formation of gap height.
\end{abstract}

\section{Introduction}

The non-engineered low-rise buildings are defined in various building categories, including residential, institutional, and commercial structures. These types of buildings are most vulnerable to be damaged during windstorm $[1,2,3]$. Typically, they were built with a minimum or no structural engineering design compared to other buildings that use codes and standards [4]. In Malaysia, rural houses are considered as non-engineered building, typically built according to the location and culture. One of the features of the rural houses in Malaysia is the presence of the core house (rumah ibu) and the extension house or kitchen house (rumah dapur) as reported by [5]. Fig. 1(a) shows an example of a rural house comprising a core and kitchen house.

Fig. 1(b) shows a rural house that suffers from roof blown-off and severe damage to the truss system during a windstorm event. Such damages are normally associated to the high uplift pressure generated at the roof of the house. [6-7] concluded that roof is the most damaging and vulnerable part of the house during windstorm as it is always subjected to the largest wind force. Failure of the roofing system is primarily from the weakness of the attachment and roofing material as stated by [8].

* Corresponding author: ceshaharudin@usm.my 
The purpose of this paper is to conduct a post windstorm evaluation on the damaged rural houses located in the northern region of Peninsula Malaysia. The aim of this study is to identify the factors that can contribute to the damage of the houses. All the information gathered from this survey can be used for future detail and in-depth analysis on the wind pressure distribution surrounding a rural house using wind tunnel test or computational fluid dynamics.

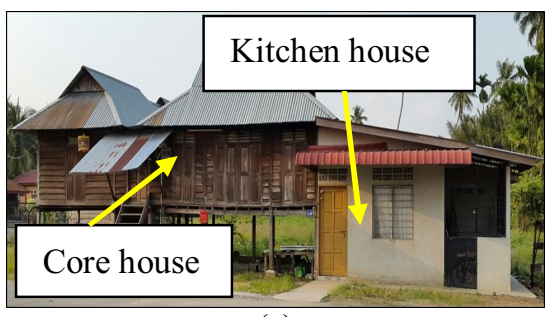

(a)

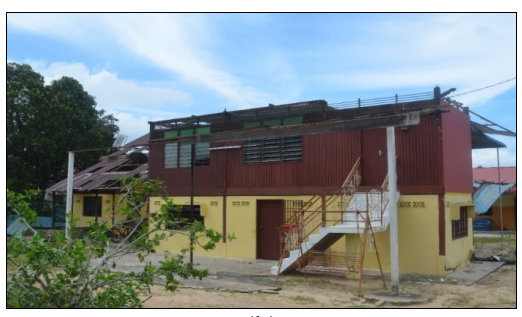

(b)

Fig. 1. (a) Core and kitchen house (b) Severe damage to the roofing system of a rural house.

\section{Post windstorm damage survey}

This study adopted the site survey method. The post windstorm survey area covered several states in the north bound of Peninsula Malaysia namely Perak, Penang and Kedah. The selected location of the damaged houses was identified via the local news. The data were collected from August 2014 until April 2016. A total of 35 houses were involved in this survey. Only those houses that suffered significant damage to the roof claddings, trusses and walls were considered.

Various activities were involved including site visualization, site measurement and interview. Site visualization involved capturing photos of the damaged houses, their surroundings and the damaged structural elements. On the other hand, the site measurement was performed in order to obtain relevant information such as the dimension of the house, roof pitch, overhang length and gap height. In addition, a sketch for each house was produced to show the overall geometry of the house and the roof. However, the findings will be discussed in other publication. The data from the site survey was presented in the form of vertical bar graph. This type of presentation is more compatible and easier to comprehend as it summarizes the number of the damage occurrences within a particular factor.

\section{Results and discussion}

\subsection{Types of damages}

Wind can cause different types of damage to the rural house such as roof blown-off, wall damage and total collapse. The survey data in Fig. 2 shows that 21 houses $(60 \%)$ experience damage at the roof of the core house only and this number is triple the houses experiencing damage the roof of the kitchen house only. In addition, 3 houses suffer damage at both roofs while another 3 houses suffer damage at the roof and wall of the core house. The survey also recorded 1 house that was totally collapsed due to the windstorm. The results matched the statement provided by $[6,7]$ where the roof system was found to be the weakest component for a low rise building. It is interesting to note that more number of roof damage was recorded for the core house compared to the kitchen house suggesting that 
presence of the gap between the two roofs and the orientation of the kitchen house may have influence the wind pressure within the vicinity of the roof area. Fig. 3 shows some examples of the damaged rural houses.

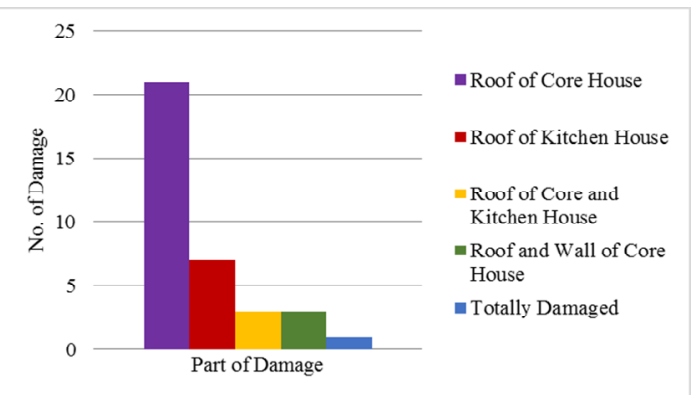

Fig. 2. Types of damages.

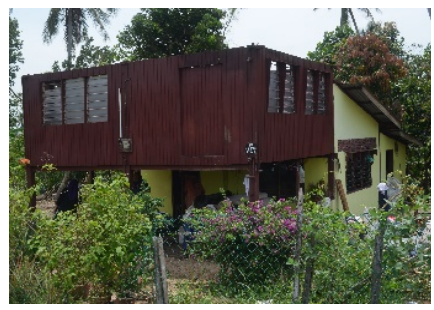

(a)

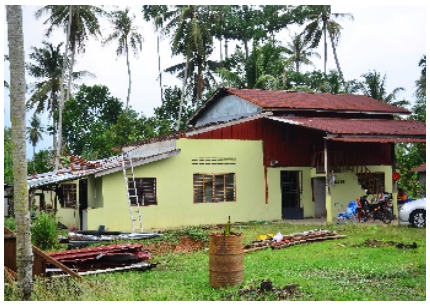

(b)

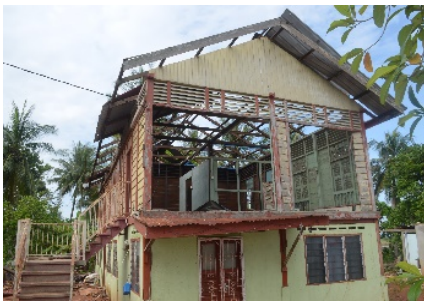

(c)

Fig. 3. Example of types of damage (a) roof of core house (b) roof of kitchen house (c) roof and wall of core house.

\subsection{Types of houses}

The main frame of rural houses was built using two different types of construction materials namely concrete and timber. Fig. 4 shows that 17 single-storey (concrete), 14 double-storey houses (concrete and timber) and 4 elevated and landed (concrete and timber) houses suffer one form of damage as presented earlier in Fig. 3.

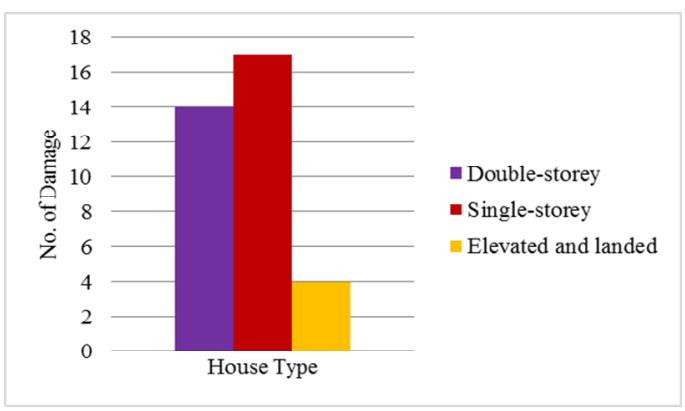

Fig. 4. Number of damage according to the types of houses.

It was thought that double-storey and elevated houses would show more number of damages due to the fact that higher structure generally will be exposed to higher wind speed 
and pressure. However, this contradicting result can be related to the difference in the gap height of between the core and kitchen house. Some typical examples of the houses are shown in Fig. 5. Obviously, the gap height for the single-story houses were smaller compared to other types of houses in this survey. The construction materials for the main frame were found to be insignificantly influencing the occurrence of damage due to fact that most all damages occurred at roof compared to other parts of the house. However, in general, timber frame is considered to be more susceptible to damage compared to concrete.

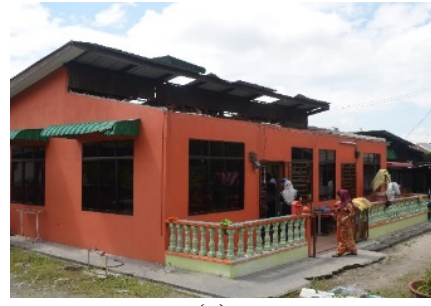

(a)

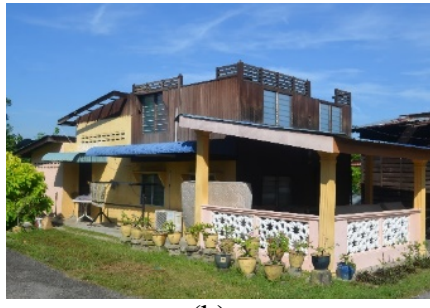

(b)

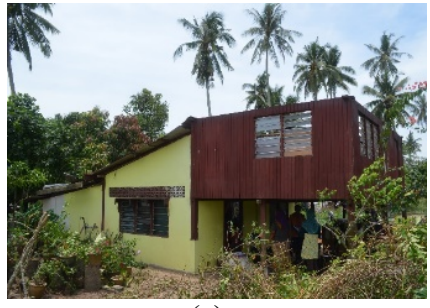

(c)

Fig. 5. Severe damage to the roof of (a) single-storey (b) double-storey (c) landed and elevated rural houses.

The survey also revealed that there were no standard dimensions to reflect a rural house. Based on the interview conducted, the size of the house was highly dependent on the available budget and current cost of construction materials. However, using a simple normalisation approach, the best ratio was found to be 3:2:1 representing the length, width and height of the house, respectively. This ratio can be used as a reference for modelling purposes.

\subsection{Gap height}

Fig. 6. shows the location of the gap between the roof of the core and kitchen house. Currently, there is very limited information in the open literature explaining the influence of the gap on the distribution of pressure surrounding the roof area.

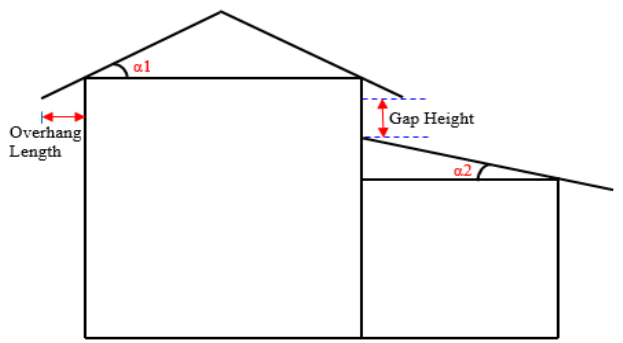

Fig. 6. Schematic diagram showing the location of the gap, the measurement of the gap height between the roof of the core and kitchen house as well as the overhang length.

However, the results in Fig. 7 show a significant trend where rural houses with small gap height are prone to damage (mostly to the roof). This statement is particularly true where 12 houses with gap height less than $0.5 \mathrm{~m}$ suffered severe damage compared to the larger ones. However, the actual number of these houses with gap height in this category may be affected because no data was made available for another 15 houses due to unforeseen matters. As the gap height increases, the number of damaged houses reduces 
significantly. Theoretically, the maximum gap height is achieved when there is no kitchen house being attached to the core house. In this case, the wind force may have directly impinged on the wall of the core house without developing any recirculation zone in the windward direction as shown in the work of [9]. As such, this finding gives an early indication on the sensitivity of the gap height and kitchen house towards the vulnerability of rural houses against windstorm.

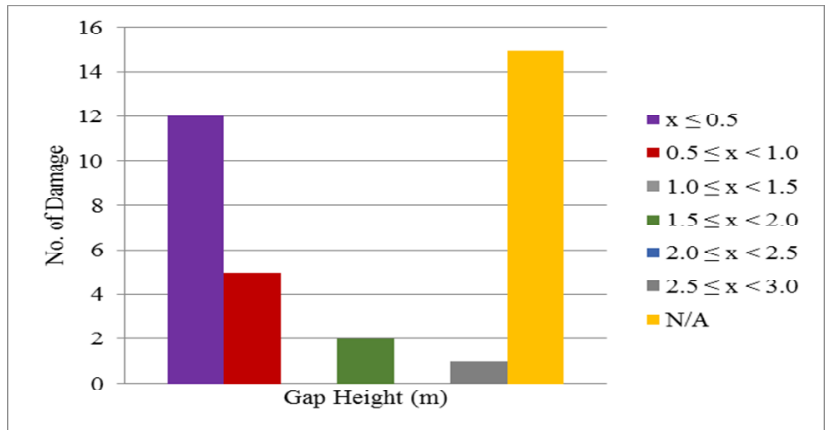

Fig. 7. Number of damages affected by the gap height.

\subsection{Overhang length}

Roof is built with overhang to protect the wall façade from being moist [10]. In Malaysia, the overhang is made been by extending the roof surface. In this case, the roofing system (cladding and rafter) at the overhang area acts as a cantilever structure. The presence of overhang may initiate damage to the roof especially when there is no adequate support to hold the roofing system from uplift. [11] reported that pressure underneath the overhang was able to account for $50 \%$ of the total wind acting on the overhang of a house.

This survey splits the number of damaged houses based on the overhang length of the core and kitchen house as shown in Fig. 8(a) and (b), respectively. To simplify the data, the overhang length is grouped according to the length within a stipulated range. It can be seen that most of the damaged rural houses are built with overhang length in the range of 0.6 to $0.9 \mathrm{~m}$ where 15 and 11 houses are affected when considering the overhang length for the core and kitchen house, respectively. The presence of overhang length may create high turbulence and uplift underneath the overhang area. The deflected flow from the windward wall increased the pressure on the lower eave surface while high suction was developed on the upper eave surface immediately after separation had occurred as reported by [10].

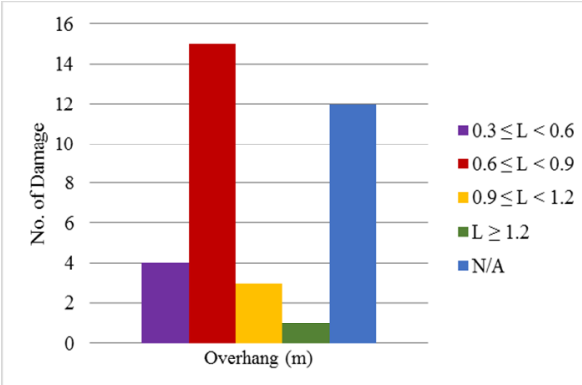

(a)

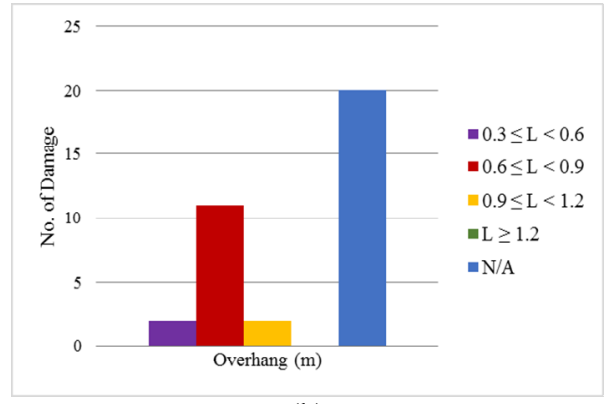

(b)

Fig. 8. Number of damages associated to the overhang length of (a) core house (b) kitchen house. 


\subsection{Roof geometry}

The geometry of the roof may have significant influence on robustness of the roofing system. It is well recognized that roof geometry can change the flow patterns around the house and building [12]. There are four different types of roof geometry that can be commonly found in the rural area namely the gable, dutch-gable, shed and lean-to (skillion) roof as shown in Fig. 9. Based on post windstorm damage survey, 29 core houses were constructed with gable roof geometry. The rest of the roof geometries showed insignificant influence on the damage and less than 3 houses were recorded for each case as shown in Fig. 9(a). $[12,13]$ proved that gable roof always recorded a high suction on the roof while [14] found that the most critical suctions values were observed near the gable end. On the contrary, 27 kitchen houses were constructed with lean-to roof geometry as shown in Fig. 9(b). It is thought that presence of wall at the far end of the roof may developed turbulence and induced uplift underneath the overhang of the roof for the core house. Fig. 10 shows some examples of the roof geometry.

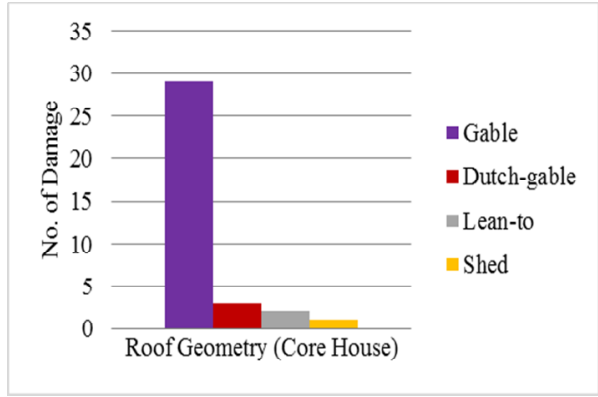

(a)

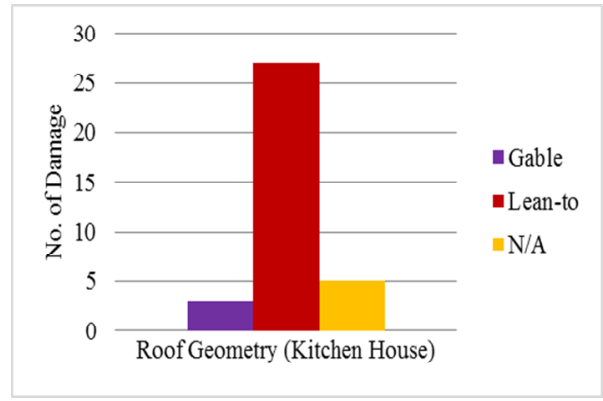

(b)

Fig. 9. Number of damages caused by roof geometry for (a) core house (b) kitchen house.

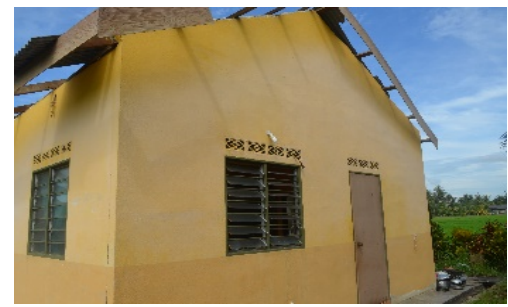

(a)

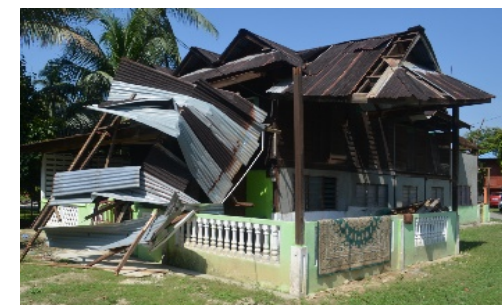

(b)

Fig. 10. Example of roof geometry (a) gable; (b) dutch-gable.

\subsection{Roof pitch}

Fig. 11(a) shows that the roof pitch of the core house for 25 damaged houses is located in the intermediate range between $7^{\circ} \leq \mathrm{x} \leq 27^{\circ}$. Similarly, the same range of roof pitch for the kitchen house also exhibits the highest number of damaged as shown in Fig. 11(b). Different roof pitches produced different flow patterns on the roof. For wind flow perpendicular to the ridge for intermediate roof, the flow separated at the leading edge, reattached on the upwind slope of roof, then separated again at the ridge. As stated by [15], this range of roof pitch was able to produce worst results and particularly true for gable roof. 


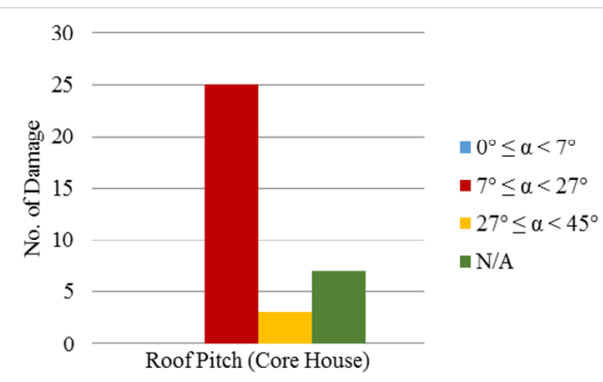

(a)

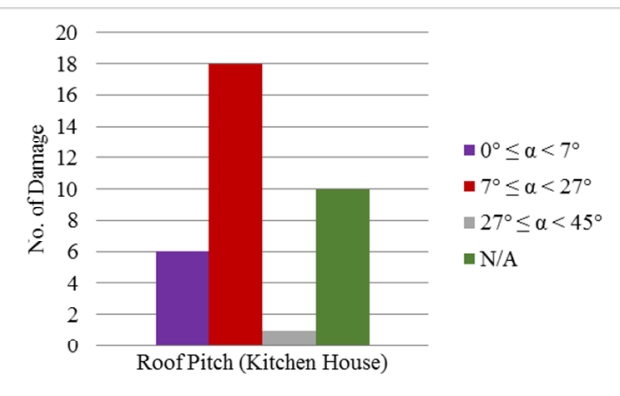

(b)

Fig. 11. Number of damages with respect to the range of the roof pitch for (a) core house and (b) kitchen house.

\subsection{Terrain category}

Fig. 12 shows that 20 of the damaged houses are located in an open terrain with no or few obstructions, commonly known as Terrain Category 1 . These areas normally cover paddy fields and water surfaces. Such areas can largely be found in the part of the mainland of Penang, Kedah and Perak. On the other hand, the other 15 damaged houses are located in an open area with a few scattered obstructions having height generally from $1.5 \mathrm{~m}$ to 10.0 $\mathrm{m}$, commonly known as Terrain Category 2. [16] reported that with increase in the surrounding obstructions, the mean wind pressure acting on the building decreased while unsteady pressure increased. Open terrain can cause a direct attack where the wind will directly impinge on the structures. Topographic features such as hills can also speed-up or slow-down the wind flow [7].

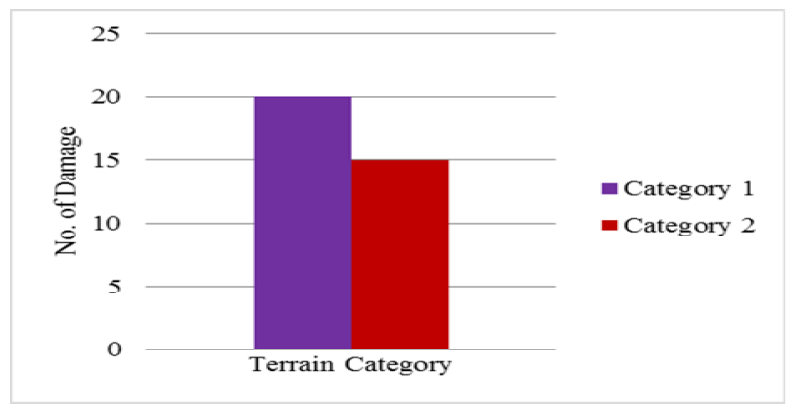

Fig. 12. Number of damages based on the surrounding conditions.

\section{Conclusions}

Based on the survey, it can be concluded that there are several critical aspects that are related to the damage to of rural houses in the northern part of Peninsula Malaysia. The critical aspects include types of damages, types of houses, gap height, overhang length, roof geometry, roof pitch, roof cladding and terrain categories. However, the degree of influence of each critical aspect or the combination of the critical aspects towards the damage requires further analysis. The presence of kitchen house also appeared to have some form of influences on the overall stability of the rural houses especially by creating the gap height between. As the construction of kitchen house is common for rural houses in Malaysia, this 
component should be included in the model for future analysis using experimental or numerical approach.

The authors express their gratitude for the financial support of the Fundamental Research Grant Scheme (FRGS) from the Ministry of Higher Education Grant (203.PAWAM.6071317), MyBrain15 Scholarship from the Ministry of Education Malaysia.

\section{References}

[1] Y. Uematsu, and N. Isyumov, Wind pressures acting on low-rise buildings, J. Wind Eng \& Ind. Aerodyn, 82, 1-25 (1999)

[2] J.D. Holmes, Wind loading of structures, Spon Press, London, UK, (2001)

[3] H.W. Tieleman, J. Wind Eng \& Ind. Aerodyn., 91(12-15), 1627-1649 (2003)

[4] M.K.A. Muhammad, T.A. Majid, N.I. Ramli, F.A. Wan Chik, and S.N.C. Deraman, An overview of Non-engineered buildings roofing system failure under wind loads Proc. of Awam Int. Conf. of Civil Engineering, Kuala Lumpur, Malaysia, (2015)

[5] S. Said, The grammar of traditional Malay long-roof houses, Proc. Post-Graduate Seminar, Universiti Teknologi Malaysia, Skudai, Malaysia, (2007)

[6] Y. Tamura, H. Kikuchi, and K. Hibi, Extreme wind pressure distributions on low-rise building models, J. Wind Eng. Ind. Aerodyn., 89, 1635-1646 (2001)

[7] J. Ginger, D. Henderson, M. Edwards, and J. Holmes, Wind-related disaster risk reduction (WRDRR) activities in asia-pacific region and cooperative actions, Int. Association for Wind Engineering, Kanagawa, Japan, (2010)

[8] F.A. Wan Chik, N.I. Ramli, M.K.A. Muhammad, T.A. Majid, and A. Hafiz, The effect of wind load on rural roofing system, Proc. of the Eight Asia-Pacific Conf. on Wind Engineering, Research Publishing, Singapore, (2013)

[9] Y. Tominaga, SI. Akabayashi, T. Kitahara, and Y. Arinami, Build. Environ, 84, 204$213(2015)$

[10] K. Narayan, and A. Gairola, Wind pressures on gable roof building with overhang, J. Wind Eng \& Ind. Aerodyn., 7(1), 16-29 (2010)

[11] K.J. Dreher and J.E. Cermak, Wind loads on a house roof, Report CER 72-73, KJDJEC22, Colorado State University, Colorado, (1973)

[12] S. Ahmad and K. Kumar, Effect of geometry on wind pressures on low-rise hip roof buildings, J. Wind Eng \& Ind. Aerodyn, 90(7), 755-779 (2002a)

[13] D. Prasad, T. Uliate, and M. R. Ahmed, Wind loads on low-rise building models with different roof configurations, Int. J. of Fluid Mechanics Research, 36, 231-243 (2009)

[14] T. Stathopoulos, K. Wang, and $\mathrm{H}$. Wu, Wind pressure provisions for gable roofs of intermediate roof slope, Wind Struct., 4(2), 119-130, (2001)

[15] S. Ahmad, and K. Kumar, Wind pressures on low-rise hip roof buildings, Wind Struct., 5(6), 493-514 (2002b)

[16] T.C.E. Ho, D. Surry, and A.G. Davenport, Variability of low building wind loads due to surroundings, J. Wind Eng \& Ind. Aerodyn, 38(2-3), 297-310 (1991) 